\title{
Methodological assumptions made in research into the benefits of ecosystem services in protected areas in the suburbs of Wrocław, Poland
}

\author{
Beata Raszka $^{1}$, Eliza Kalbarczyk ${ }^{2}$ \\ ${ }^{1}$ Wroclaw University of Environmental and Life Sciences, Department of Spatial Management \\ ul. Grunwaldzka 53, 50-357 Wroclaw, Poland; e-mail: beata.raszka.@up.wroc.pl; \\ ${ }^{2}$ Adam Mickiewicz University, Faculty of Geographical and Geological Science, Institute of Socio-Economic \\ Geography and Spatial Management, Department of Spatial Economy \\ ul. Dzięgielowa 27, 61-680 Poznan, Poland; e-mail: ekalb@amu.edu.pl
}

\begin{abstract}
This paper presents the methodological assumptions made in research into ecosystem services in communes near the city of Wrocław which lie within the protected areas of landscape parks and are subject to suburbanization. These ecosystem services were categorized as follows: services to humans (pati), services to ecosystems (dare), prevention or inhibition of services (facere/non facere). The services were assessed using a transformation index $\left(\mathrm{W}_{\mathrm{t}}\right.$, an urbanization rate (WU) and a preservation index $\left(\mathrm{W}_{\mathrm{p}}\right)$. Spatial management in the communes was evaluated using the Overall Sustainable Development Indicator (OSDI). The findings of this research could serve as helpful guidance in the creation of ecosystem policies in areas subject to suburbanization.
\end{abstract}

Keywords: ecosystem services, urban sprawl, protected areas

\section{INTRODUCTION}

Research into ecosystem services, which is an area of research based mainly on economic sciences, is relatively new. The mid-20th century saw the emergence of the idea that capital, the market and labour can provide a remedy for a shortage of natural resources (Gómez-Baggethum et al. 2010), and the external costs and benefits of environmental protection in this context gradually started to enter the picture. It is now widely acknowledged that economic decision-making should always take into account the quality of environmental and natural resources. It is also accepted that any research into the gains and losses connected with the functioning of ecosystems should be multidisciplinary, in line with the fundamental paradigm of sustainable development in which the environmental and economic spheres are seen as equivalent, interdependent and interwoven. Thus far, the relationship in Poland between ecological systems (ecosystems) and their services has not been defined in the context of natural sciences.
Indicators of sustainable development (Borys 2005) refer to technical activities and deal exclusively with services obtained (i.e. with goods and services derived from ecosystems). The analyses of ecosystem services in research done by PR Ehrlich and AH Ehrlich (1981) refer to services and goods obtained due to the existence of ecosystems. Economic evaluation of products and services obtained from the environment distinguishes four categories of ecosystem services (Constanza et al. 1997, Daily 1997, Mizgajski 2010): supply services (raw materials, food and other biological resources); regulatory services (regulation of climate, air quality and biological processes); supporting services (circulation of elements and compounds, primary production, water cycle, habitat functions); and cultural services (aesthetic, recreational, spiritual, cognitive and educational functions).

There are no comprehensive economic programmes for the maintenance of ecological systems and the processes within those systems; therefore, there is no spatial planning policy which takes into account environmental development and protection. This issue becomes especially burning in areas subject to suburbanization, and in Poland it has also intensified over the last decade, in particular after 2004 (i.e. after Poland's accession to the European Union). It mainly concerns areas close to cities which have high economic growth rates and which attract a large amount of migration. However, control and codification of these factors are possible with the help of a well-administered local land use policy and local rules concerning property rights. In order to achieve this, it should be recommended that communes use the planning procedures contained in their local development plans. Thus established local planning procedures should determine land use, including assessment of environmental cost. The details of these local plans can then be analysed in the context of the theory of ecosystem services. In 2007, only $24.1 \%$ of the area of Poland was covered by local development plans (Śleszyński and Solon 2010). However, the essence of the problem lies not in this per se, but in the lack of coordination between local plans and the 
actual intended use of the land, and also in the failure to consider the functional dependency of the two. In environmentally valuable areas, inconsistencies may also be observed between the economic functions set out in the local development plan and the function of the buffer zone (Raszka and Kasprzak 2012). In this article, we will present methodological assumptions that allow for the mutual relationship between man and the environment. We will propose an evaluation of ecosystem services based on the following three categories:

1. ecosystem services to humans,

2. services to the ecosystem (compensation),

3. prevention or inhibition of services (status quo).

The purpose of this research was to formulate theoretical principles of methodology for research on ecosystem services, in the context of the suburbanization taking place near Wrocław (SW Poland). The results of this research could serve as helpful guidance with regard to ecosystem conditions in developing planning policies for the environment in areas subject to suburbanization.

\section{METHODS}

This study covers two different sets of communes (the commune (Polish: gmina) is the principal unit of Poland's administrative division at its lowest uniform level) (Fig. 1):

a) four communes in the district of Wrocław which include land covered by landscape parks [in Poland a landscape park is a protected area with a lower status than that of a national park and with less stringent restrictions on development and economic use. According to the Nature Protection Act (2004), a landscape park is defined as "an area protected because of its natural, historical, cultural and scenic values, for the purpose of conserving and popularizing those values in conditions of balanced development"]: Jordanów Śląski and Sobótka (both including part of the Ślężański Landscape Park) and Kąty Wrocławskie and Mietków (both including part of the Bystrzyca Valley Landscape Park)

b) five communes in the district of Wrocław located outside landscape parks (Długołęka, Czernica, Siechnice, Żórawina and Kobierzyce).

In this paper, we suggest that the humanenvironment relationship should be seen in the following way:

a) as giving (Latin: dare) something from ecosystem services to humans (for example urbanization, mineral extraction, change of land use from agricultural to non-agricultural),

b) as providing compensation (Latin: pati), that is, human services to the ecosystem (for example forestation, the inclusion of biologically active areas in urban planning, reclamation),

c) as doing/not doing something (Latin facere/non facere): that is, the prevention or inhibition/retardation of anthropic impact (for example defining protected areas, ensuring the sustainable use of seminatural ecosystems, prevention of environmental contamination).

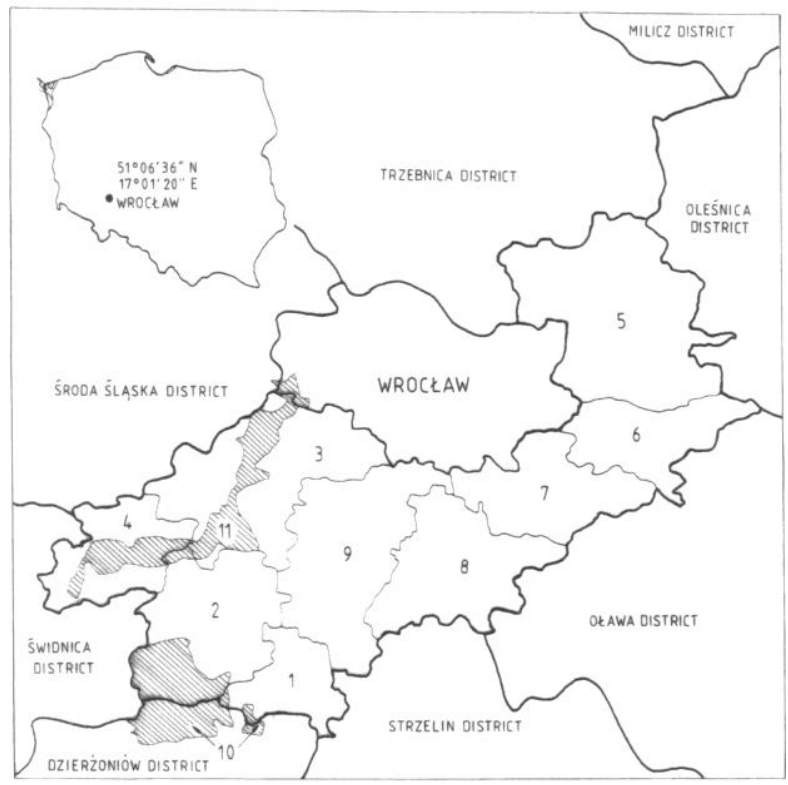

Fig. 1: Location of the study area

Commune: 1 - Jordanów Śląski, 2 - Sobótka, 3 - Kąty Wrocławskie, 4 - Mietków, 5 - Długołęka, 6 - Czernica, 7 Siechnice, 8 - Żórawina, 9 - Kobierzyce; Landscape Parks: 10 - Ślężański, 11 - Dolina Bystrzycy (original)

The fulfilment of the purpose of this research involves making the following assumptions:

1. That the giving from ecosystem services to humans (dare) consists in changes in the use of natural and semi-natural ecosystems, and therefore in the reduction of biologically active areas. This type of service predominates in the case of land located outside a protected area. In contrast, in communes with mixed functions (i.e. both protective and economic), ecosystem services are dominated by pati and non facere services.

2. That human-environment relationships are determined by the principles of spatial policy and spatial management adopted by a particular commune. These become the officially-defined relationship between man and the environment. This relationship can also be defined using the categories of dare, pati, facerelnon facere.

3. That the spatial policy adopted by a particular commune forms the basis of any compensatory activities (e.g. land rehabilitation) and preventive activities (e.g. inhibiting the rate of ecosystem services to humans through the planned reduction of agrocenose use). Spatial policies are then determined with reference to indicators which demonstrate the spatial capacity of the environment and allow for a permissible level of human pressure which does not violate the principle of sustainable development.

4. That it is possible to standardise planning activities in communes which are located in protected areas (e.g. landscape parks). Establishing a common 
pattern of conduct (here, an environmental policy based on indicators which evaluate each type of ecosystem service) allows the maintenance of a dynamic balance between ecosystem services and services to ecosystems (anthropogenic homeostasis).

In this paper, we have assumed that ecosystem services resulting from the provisions contained in planning documents (i.e. studies on the conditions and directions of spatial management, and local development plans) denote a relationship between the state of the environment before and after the adoption of the planning policy contained in the document, which can be determined by the following formula:

$$
E S=|A b| \div|A a|
$$

where:

ES - ecosystem service

$\mathrm{Ab}$ - the area of the examined ecosystem before the preparation of a planning policy [ha]

$\mathrm{Aa}$ - the area of the examined ecosystem after the preparation of a planning policy [ha]

ES assumes the following values:

$\mathrm{ES}=1-$ no change in the ecosystem area

$\mathrm{ES}<1-$ a decrease in the ecosystem area

ES $>1-$ an increase in the ecosystem area

The following factor analyses were proposed in order to define human-environment relationships as an expression of ecosystem services:

a) dare relationship - ecosystem services to humans:

Transformation rate $\left(\mathrm{R}_{\mathrm{t}}\right)$,

$$
R_{t}=\sum A_{t} \div \sum A_{n t}
$$

where:

$\Sigma \mathrm{A}_{\mathrm{t}}-$ the total area of transformed land [ha]

$\Sigma \mathrm{An}_{\mathrm{t}}-$ the total area of non-transformed land [ha]

b) pati relation - human services to the ecosystem:

Urbanization rate $\left(\mathrm{R}_{\mathrm{u}}\right)$ :

$$
R_{u}=A_{u} \div A_{B}
$$

where:

$\mathrm{A}_{\mathrm{u}}$ - the area of urbanized land

$A_{B}$ - the area of biologically active land with natural processes predominating

f) facere/non facere relationship (doing/not doing something) - prevention or inhibition (retardation):

Preservation index $\left(\mathrm{I}_{\mathrm{p}}\right)$ :

$$
I_{p}=A_{n t} \div \sum A_{c l}
$$

where:

$\mathrm{A}_{\mathrm{nt}}$ - non-transformed land [ha]

$\Sigma \mathrm{A}_{\mathrm{cl}}$ - total area of land used in the final year of the period studied [ha]

An assessment of the Overall Sustainable Development Indicator (OSDI) for the commune was also calculated according to the following formula:

$$
O S D I=\sum\left[S D I_{(i)} \times w(i)\right] \div \sum[w(i)]
$$

where:
OSDI - the overall assessment of sustainable development in the commune

SDI (i) - the value of the $i$-th partial indicator of sustainable development in particular areas

$\mathrm{w}(\mathrm{i})$ - the weight of the $i$-th indicator, which is dependent on the type of space, as follows:

a) protected non-urbanized area [weight 1.0] land covered by water and forest, high quality agricultural land, or land under any other form of protection

b) non-urbanized area, viewed as a potential area of development [weight: 0.7] - other arable land, wasteland, various other types of land, and quarries

c) urbanized area [weight: 0.1] - built-up land and transportation routes

This factor analysis permits an objective assessment and determination of the intensity and type of environmental change. These indicators permit the determination of the type of ecosystem service predominating in each of the analysed communes, and also the categorization of each commune based on the predominance of a particular type of ecosystem service (pati [a], dare [b] or facere/non facere [c]). On this basis, it is then possible to establish principles for sustainable planning and land management. We propose that the following spatial activities resulting from planning provisions be assigned to each category of service: permission for a variation in land use, exclusion from agricultural production or compensation activities which limit the process of urbanization. Factor analysis of ecosystem services, as a comparative method, marks a significant progression in the assessment of the real effects of spatial policies, planning and land use management at the local (i.e. communal) level. This should enable actions which have been carried out in accordance with current spatial policies to be corrected. Thus, this method should give support to planning solutions which are seen in terms of compensation and in terms of the prevention and inhibition of actions which are detrimental to ecosystems. Activities which are aimed at restricting dare services need to be applied to the economic activities carried out in communes situated in protected areas.

\section{DISCUSSION}

The assessment of ecosystem services is a subject of interest to a number of international bodies. The European Commission has worked on a proposal for implementing ecological sustainability thresholds (Communication... 2009). One of this proposal's main goals is to respect the fact that our planet has limited natural resources, which also includes the natural world's limited possibilities of providing renewable resources and absorbing pollution. Ecosystem services are considered to be provided if the following criteria are met: the transaction is voluntary, the ecosystem services are well-defined, there is at least one purchaser, and there is at least one provider of services (Wunder 2005). It is essential to 
approach land use in terms of the gains and losses which are made by both the environment and the economy. According to this approach, man (the economy) and the environment both play a role as stakeholders. The environment is sometimes a service provider and sometimes a service purchaser. In areas that are subject to suburbanization, the environment is the providing side. The identification and evaluation of ecosystem services provides significant support for pro-environmental arguments when economic decisions are made, e.g. the location of investments. In sustainable environmental management it is essential to limit the cost to the environment and to ensure the proper functioning of its ecosystems. Ecosystem services are brought about through planning solutions that change the pattern of land use, allocate commercial functions to ecosystems and intensify the use of both natural and extensively-used semi-natural ecosystems.

Under the current legislative framework (The Planning and Land Use Act 2003), it is communes that are responsible for the state of the local environment. Each commune has its own independent spatial policy and makes local laws concerning the environment. This issue is of particular importance in areas subject to suburbanization, especially those which are also part of a protected area. The systemic and socioeconomic transformations in the countries of Central and Eastern Europe were responsible for a stage of very intense changes in the functional and spatial structures of large cities and their suburbs. The greatest transformation occurred in metropolitan areas (Degórska 2004). In the Warsaw area, houses are now being built primarily in non-forested areas between existing settlements. The most popular of these are the areas immediately surrounding forests, particularly in the Mazowiecki and Chojnowski Landscape Parks. In effect, these sprawling urban areas are isolating the forested areas in strips or islands (Degórska, 2004). A similar pattern can be observed in the Poznań area in the vicinity of the Wielkopolski National Park and the Puszcza Zielonka Landscape Park (Kasprzak and Raszka 2010, Raszka 2006, Raszka and Kasprzak 2008, 2012). Suburbanization is associated with a decrease in the density of population in the centres of cities and increased population density in the suburbs, but with the migration balance of the conurbation as a whole remaining steady (Berry 1976, Klaassen and Paelinck 1979). Areas of suburbanization are areas that were previously open, seminatural, and mainly agricultural (i.e. arable land or meadowland); they are located particularly in the vicinity of lakes and forests. This agricultural function is gradually diminishing due to urbanization and suburbanization. In communes which also contain land forming part of landscape parks, this function is gradually being replaced by the functions of recreation and tourism. In Poland, these processes have been chaotic, and this has intensified since Poland's accession to the European Union in 2004 and the resultant improvement in the economic situation of many Poles. Wrocław is currently the fastest growing metropolis in Poland. In 2009, the migration balance in the Wrockaw district was +3183 , and in the city of Wrocław itself +819 (Local Database of the Central Statistical Office 2010). This proves that the area is very attractive to people from other parts of the country; this in turn is not only a result of the subregion's relatively more advantageous economic conditions, which is reflected in better chances of finding and keeping a job there, but also of the changing lifestyle of Polish people, which includes a greater propensity to settle in areas immediately outside the regional metropolis. Population growth stimulates urbanization, which has adverse effects, such as a scattered pattern of development, building construction on high-quality soil, and the development and intensification of commercial functions within the general proximity of protected areas and even in their buffer zones. According to Przewoźniak (2005), suburbanization results mainly in extensive and complex settlements with varied levels of urban functions and various intensities of land use, a significant densification of the technical infrastructure which connects individual settlements, and the disapperance or disintegration of natural areas as a result of suburbanization. In American literature on the subject, this process is known as urban sprawl (Bruegmann 2005). This phenomenon is often not regulated, as suburban areas are not treated as entities which require balanced development. The attitude of man towards natural resources has always been determined by economic factors (Żylicz 2010). The main motivation has been economic gain and rarely have future consequences been taken into consideration. Nowadays, it is considered to be necessary to examine all the costs and benefits associated with the management of ecosystems; this is not only based on the ecosystem theory, but also on various economic ideas about the connection between economic processes and the environment (e.g. Mooney and Ehrlich 1997). In the mid-20th century, it was thought that capital, labour and the market mechanisms could be a remedy for a deficiency of natural resources (Hubacek and van der Bergh 2006); however, this idea proved to be inadequate even on a theoretical basis. The degradation of the environment on a global scale quickly made it necessary to determine the external costs and benefits of protecting the natural environment. The making of decisions concerning physical space has increasingly required consideration of the quality of the environment and natural resources.

With the ecosystem having been recognised as a proper subject for research - and one which is also significant in the development of economic theories its principal services to humans were then assessed. These services include: the prevention of pest gradation, pollination of plants, development of fish stocks, influence on climate, prevention of soil erosion, regulation of freshet waves, soil formation, and the circulation of matter in the environment. In an attempt to assess the monetary value of ecosystem services on a global scale, first 17 functions of ecosystems were identified and categorised as non- 
material or material services. This created a basis for estimating the global monetary value of ecosystem services (Constanza et al. 1997). This method was used, inter alia, in carrying out the global project "The Millenium Ecosystem Assessment" (MEA) (2005), whose aim was to assess the influence of changes in the ecosystem on human wealth. In reality, the basic function of the ecological system is the circulation of matter and energy. All the other functions mentioned above are merely derivatives of this function, or actually have no real connection with the processes taking place in the ecosystem. Spatial planning, as the basic instrument for shaping the natural environment of human beings, aims to establish order on a spatial level. In the wider sense, spatial planning aims to formulate concrete patterns (projects) which have the aim of changing spatial reality (Gasparski 1978, after Lojewski 1997) so that any change is rational, efficient, permissible (that is, legally fair) and not aesthetically negative. The general principles of changing the environment in geographical areas covered by planning documents (including the process of urbanizing) are fourfold (Andrzejewski 1975, 1981):

- preserving biodiversity and ecological niches

- preserving the continuity of ecosystems in time

- preserving the continuity of ecosystems in space

- ensuring the adequacy of ecosystems with regard to abiotic conditions.

\section{CONCLUSION}

Planning and design are activities aimed to find ways in which a given system might function optimally (e.g. technical devices, organizational structure, spatial structure, economy) that would meet any efficiency criteria applied to it (Lojewski 1997). The goal of designing and doing empirical studies is to solve specific practical problems, to estimate the factors (parameters) of theories and to propose optimal solutions, which are then formulated in more practical details within the domains of individual practical sciences. Each discipline is interested in the reality of one specific aspect of a given object, whilst changing that reality requires consideration of all the aspects of that object (Gasparski 1978, after Łojewski, 1997). Planning should lead to a synthesis of every aspect of the design that serves as the basis of the solution implemented. Therefore, changing the reality of any given system requires all the partial studies conducted in relation to it (i.e. those belonging to specific sciences which describe this reality in their respective languages) to be taken into account; only then can a redesign of this reality be incorporated into the environment harmoniously. Research carried out within the boundaries of conurbations and in protected areas adjacent to them (e.g. Kozłowski 2006 Kozłowski and Legutko-Kobus 2007, Kasprzak and Raszka 2008, Korzeniak 2009, Łowicki 2008) indicates that all the different spatial units of the environment should be treated as a whole, in which the transformation of ecosystems should be analysed and planned comprehensively for that whole. This is of particular importance in the case of environmentally valuable areas subject to intense spatial transformation, especially those in the proximity of large cities. In the case of a spatial policy, including a local spatial policy, it is important to realise that there exist endangered zones before such zones reach a critical point of danger. By realising this, it is possible to determine appropriate alarm thresholds. The dynamics of spatial transformations taking place in functional environmental areas show that spatial planning at the communal level is often insufficient to preserve the basic environmental functions of a given area in its entirety. It is therefore necessary to search for simple indices that allow ecosystems in the whole area covered by a commune or a region to be developed in line with the principles of sustainable development.

\section{Refrences}

[1] Andrzejewski R.: Ecological problems of shaping the urban environment. [in Polish] Wiad. Ekol. 21,3: 175-186, 1975.

[2] Andrzejewski R.: Ecophysiography and ecological development of the biotic environment in urban areas, [in Polish] Człowiek i Środowisko, 4, 4:5-20, 1981.

[3] Berry, B.J.L.: The counterurbanization process: Urban America since 1970, in: Berry, B.J.L. (ed.) Urbanization and counterurbanization, Sage Publication, Beverly Hills-London, pp. 17-30, 1976.

[4] Borys T.: Indicators for sustainable development - Polish experiences, Ekonomia i Środowisko, Warsaw-Białystok, 2005.

[5] Bruegmann R.: Sprawl, a compact history, The University of Chicago Press, Chicago-London, 2005.

[6] Communication from the Commission to the Council and European Parliament. Beyond GDP. Measuring progress in a changing world. Commission of the European Communities, Brussels, 2009.

[7] Constanza R., D’Arge R., de Groot R., Farberk S., Grasso M., Hannon B., Limburg K., Naeem S., O’Neill R.F., Paruelo J., Raskin R.G., Suttonkk P., van den Bel M.: The value of the world's ecosystem services and natural capital. Nature, 387: 253-260, 1997.

[8] Criteria of ecological absorption in spatial planning. Final Report, Institute of Spatial Planning and Housing, materials of the Ministry of Environment, [in Polish] mscr. 2007.

[9] Daily G.C.: Nature's services: Societal dependence on natural ecosystems. Island Press, Washington D.C., 1997.

[10] Degórska B.: Planning of open spaces in new urban areas (based on the example of the suburban zone of Warsaw) [in Polish] in: M. Kistowski (ed.), Ecological and landscape studies in the programming of sustainable development. 
Overview of Polish experiences at the threshold of European Union integration, [in Polish] Gdańsk, pp. 141-148, 2004.

[11] Ehrlich P.R., Ehrlich A.H.: Extinction: the causes and consequences of the disappearance of species. Random House, New York, 1981.

[12] Gómez-Baggethum E. et al., The history of ecosystem services in economic theory and practice: from early notions to markets and payment schemes, Ecological Economics, 2010, vol. 69 , No. 6.

[13] Hubacek K., van der Bergh J.: Changing concepts of land in economic theory: from single to multi-disciplinary approaches, Ecological Economics, No. 56, pp. 5-27, 2006.

[14] Kasprzak K., Raszka B.: Changes in land use in the vicinity of protected areas, [in Polish] in: S. Karczmarek (ed.): Landscape and biodiversity, pp. 62-81, 379. Kazimierz Wielki University, Bydgoszcz, 2008.

[15] Klaassen L.H., Paelinck J.H.P.: The future of large towns. Environment and Planning A11(10), pp. 1095-1104, 1979.

[16] Kozłowski S. (ed.): Urban sprawl. The growing problem of conurbations in Poland, [in Polish] Catholic University of Lublin, BiałystokLublin-Warsaw, 2006.

[17] Kozłowski S., Legutko-Kobus P. (eds): Spatial planning. Opportunities and threats to the society and the environment, [in Polish] Catholic University of Lublin, Lublin, 2007.

[18] Korzeniak G.: The transformation of the spatial structure surrounding the Niepolomice Forest, [in Polish] in: Problems of urban development, vol. 1-2/2009, pp. 118-131, Cracow, 2009.

[19] McGarigal K., Marks B.J., FRAGSTATS: Spatial pattern analysis program for quantifying landscape structure. General Technical Report PNW, US Forest Services, Portland OR, USA, 1994.

[20] The Millennium Ecosystem Assessment, Ecosystems and Human Well-being: Synthesis. Island Press, Washington, 2005.

[21] Mizgajski A.: Ecosystem services as a developing field of research and applications, [in Polish], Ekonomia i Środowisko, 1(37):125-139, 2010.

[22] Łojewski S.: Elements of spatial system design methodology, [in Polish] University of Technology and Life Sciences in Bydgoszcz, 1997. [23] Łowicki D.: Wielkopolska landscape changes from the beginning of the systemic transition, [in Polish] Adam Mickiewicz University, Poznań, 2008.

[24] Mooney H.A., Ehrlich P.R.: Ecosystem services: A fragmentary history, in: Nature's Services: Societal Dependence on Natural Ecosystems, ed. G.C. Daily, Island Press, Washington, pp. 11-19, 1997.

[25] Przewoźniak M.: Ecological aspects of suburbanization - theory and practice, [in Polish] in: Lorens P. (ed.), The problem of suburbanization, Biblioteka Urbanisty No. 7, Warsaw, pp. 127-134, 2005.

[26] Raszka B.: Expansion of the "greater Poznan" - conditions, consequences, prevention, in: Kozłowski S. (ed.): Urban sprawl. The growing problem of conurbations in Poland, [in Polish] pp. 201-223, Catholic University of Lublin, Białystok-Lublin-Warsaw, 2006.

[27] Raszka B., Kasprzak K.: Ecosystem services in spatial planning - study of case of the Wielkopolski National Park, Ekologia, vol. 31, No. 2, pp. 182-193. Bratisłava, 2012.

[28] Sołtys J.: Methods of strategic planning in communes allowing for spatial aspects and sustainable development, [in Polish] Gdańsk University of Technology, monographs nr 87, Gdańsk, 2008.

[29] Śleszyński P., Solon J.: Planning and spatial conflicts in communities, [in Polish] Studia, vol. CXXX, PAN KPZK, Warsaw, 2010.

[30] Wunder S.: Payment for environmental services: some nuts and bolts. CIFOR Occasional Paper, No. 42, p. 32, 2005.

[31] Żylicz T.: Valuation of ecosystem services. [in Polish] Ekonomia i Środowisko, No. 1(37):31-45, Ekonomia i Środowisko, Białystok, 2010.

[32] http://www.stat.gov.pl/bdl; The Local Database of the Central Statistical Office in Poland, 2010. 